\title{
ANALISIS KESALAHAN FONOLOGIS DALAM KETERAMPILAN MEMBACA TEKS BAHASA ARAB
}

\author{
Fitria Lathifah, Syihabuddin, M. Zaka Al Farisi \\ Universitas Pendidikan Indonesia, Indonesia \\ tialathifab@gmail.com
}

\begin{abstract}
This research aimed to analyze the phonological errors made by the students of Arabic department when processing of learning activity about reading skill. The research design used in this research was content analysis. The data collection method used was listening method with free listening-speaking technique, writting technique and recording technique. The result of this research showed up that the students' phonological errors that often occured were on fricative sound such as ( ح ذ ط ش

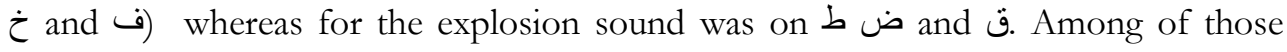
errors, the most difficult and the biggest errors were $\mathcal{\varepsilon}$ and
\end{abstract}

Keywords: analysis of linguistic error, phonology, reading skill

\section{Abstrak}

Penelitian ini bertujuan untuk menganalisis kesalahan fonologis yang dilakukan oleh mahasiswa jurusan bahasa Arab saat mereka melaksanakan aktivitas belajar keterampilan membaca. Penelitian ini menggunakan desain penelitian dengan analisis isi (content analysis). Untuk mengumpulkan data penelitian, metode yang digunakan adalah metode mendengarkan dengan teknik free listening-speaking, teknik menulis dan teknik perekaman. Hasil penelitian ini menunjukkan bahwa kesalahan fonologis siswa yang sering terjadi pada saat kegiatan membaca adalah pada suara frikatif seperti (

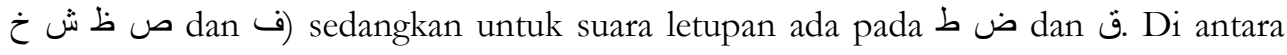
kesalahan-kesalahan tersebut, kesalahan yang paling sulit dan paling banyak adalah pada pelafalan huruf 2 dan ض.

Kata Kunci: analisis kesalahan bahasa, fonologi, keterampilan membaca 


\section{Pendahuluan}

Fonologi merupakan salah satu cabang linguistik yang membahas tentang bunyi. Bunyi yang dimaksud adalah tuturan. Tuturan yang baik dan benar tentu akan dipahami oleh pendengar. Ketepatan pengucapan dalam sebuah tuturan adalah hal yang penting karena dapat mempengaruhi makna yang dimaksud oleh penutur. ${ }^{1}$ Sesuai dengan pernyataan di atas, jelaslah bahwa untuk mampu mengucapkan bunyi-bunyi huruf dengan baik dan benar, maka perlu kiranya setiap pembelajar bahasa memulainya dengan mempelajari fonologi. Sebaliknya jika pembelajar bahasa tidak lebih dulu mempelajari fonologi, maka tentu dalam proses pembelajaran akan menimbulkan berbagai kesalahan. Kesalahan dalam pengucapan huruf, dapat berpengaruh pada makna semantik. Maka sangat jelas bahwa unsur bunyi dalam bahasa Arab menjadi sangat penting untuk dipelajari dengan maksud agar pengucapan huruf bahasa Arab sesuai dengan aturan yang telah ditetapkan. ${ }^{2}$

Fokus penelitian ini mengidentifikasi kesalahan-kesalahan fonologis berdasarkan titik artikulasi, sifat huruf dan gelombang bunyi. Selain mengidentifikasi kesalahan, penelitian ini pun bertujuan untuk mengklasifikasi dan mendeskripsikan kesalahan tersebut. Jika pengklasifikasian berdasarkan titik artikulasi dan sifat huruf dapat diidentifikasi dengan teori yang bersangkutan, sedangkan pengklasifikasian kesalahan berdasarkan gelombang bunyi, peneliti menggunakan aplikasi Praat. Aplikasi ini dapat merekonstruksi tuturan sehingga menghasilkan visualisasi tuturan berupa gelombang bunyi. Dengan hasil rekonstruksi tersebut, peneliti dapat mengklasifikasikan berbagai kesalahan ke dalam beberapa gelombang bunyi (gelombang bunyi aperiodik, periodik dan transien).

Kesalahan fonologis merupakan salah satu bentuk kesalahan yang termasuk ke dalam taksonomi linguistik. Kesalahan tersebut terjadi pada tataran bunyi, baik pada level kata, frasa, klausa atau kalimat. Kesalahan pada aspek fonologi terjadi dalam penggunaan bahasa lisan, baik secara produktif (berbicara) maupun reseptif (mendengar). ${ }^{3}$ Berikut merupakan contoh dari kesalahan pelafalan dalam bahasa Arab pengucapan المَطَرُ (bajan) menjadi المَطَرُ (banda).

Kesalahan fonologis ini terjadi di salah satu sekolah berdasarkan hasil observasi dan wawancara dengan beberapa siswa kelas VII F SMP Plus Baiturrahman 2, para siswa mengungkapkan bahwa mereka belum mampu membedakan dan melafalkan bunyi huruf hijaiah, baik dari segi lisan maupun tulisan, sehingga menjadi sebuah problema dalam proses pembelajaran bahasa Arab. Padahal orientasi mempelajari bahasa Arab sangatlah banyak. Salah satu orientasi yang tepat bagi siswa adalah mampu memahami ilmu agama yang tertera dalam Alquran. ${ }^{4}$ Karena itu modal utama untuk belajar bahasa Arab adalah mampu membaca huruf hijaiah dengan baik

${ }^{1}$ K. Wardana. Kesalahan Artikulasi Phonemes Bahasa Inggris Mahasiswa Prodi Bahasa Inggris UNMAS Denpasar: Sebuah Kajian Fonologi Generatif. Jurnal Bakti Saraswati. 2014, 77.

${ }^{2}$ M. Subali, et.al. "Frekuensi Forman sebagai Model Akustik Tabung Sederhana dari Vocal Tract”. Prosiding Seminar Nasional Aplikasi Sains \&Teknologi (SNAST). 2014, 41.

${ }^{3}$ Setyawati. Analisis Kesalahan Berbahasa Indonesia. (Yuma Pustaka. 2013), 17.

${ }^{4}$ S.E. Lubis. "Orientalis dan Bahasa Arab”. Jurnal Forum Pedagogik. 2015, 103. 
dan benar. Ketidakmampuan siswa dalam membedakan huruf hijaiah ini ternyata terjadi di kelas atas yaitu kelas VIII dan IX artinya bahwa pembelajaran bahasa Arab selama ini tidak menekankan kebenaran pelafalan fonetik Arab.

Inilah alasan peneliti memilih kelas VII F sebagai sampel penelitian, karena kesalahan yang terdeteksi lebih awal akan mudah diperbaiki. Seperti ungkapan "meluruskan kesalahan lebih dini, lebih baik". Kesalahan yang terjadi di kelas VII akan lebih mudah diperbaiki sehingga nantinya tidak akan terjadi di kelas VII dan IX. Hal ini berhubungan dengan fosilisasi kesalahan berbahasa, yaitu kesalahan yang tidak dapat dipulihkan. Fosilisasi adalah kondisi yang stabil pada level kompetensi bukan bahasa target atau interlanguage. ${ }^{5}$ Kesalahan yang diperbuat siswa dalam proses belajar tidak dapat dipandang sebagai kesalahan mutlak, akan tetapi harus dipandang sebagai bagian dari strategi belajar. ${ }^{6}$ Kesalahan yang memfosil merupakan sifat kesalahan dimana kesalahan itu telah tinggal sebagai potensi yang sewaktu-waktu akan muncul dalam performansi. Oleh karena kesalahan itu sudah menjadi potensi, kesalahan tersebut menjadi biasa dan lama kelamaan tidak dianggap kesalahan lagi. Jadi, fosilisasi adalah bentuk-bentuk linguistik yang salah, tetapi karena bentuk-bentuk itu selalu digunakan, kesalahan itu dianggap biasa.

Penelitian serupa yang terkait dengan fonologi memiliki hasil penelitian yang menunjukkan bahwa orang dari suku Dayak, Jawa, Melayu, Sunda dan Mbojo melakukan kesalahan fonologis dalam melafalkan huruf ض ض, ع, ط, ص عaktor penyebab orang Indonesia melakukan kesalahan di antaranya adalah keadaan lidah yang tidak terbiasa melafalkan huruf Arab, tertukarnya dengan huruf lain, asumsi terhadap huruf/bahasa Arab yang sulit, tidak tahu aturan-aturan atau kaidah melafalkan huruf Arab, kebiasaan berbahasa Ibu dan minat orang Indonesia untuk mempelajari Alquran. ${ }^{7}$

\section{Metode Penelitian}

Penelitian ini menggunakan metode penelitian deskriptif kualitatif, karena peneliti melakukan pencarian fakta dengan interpretasi data yang ditemukan. Adapun desain penelitian yang digunakan adalah analisis isi (content analysis), karena data yang digunakan berupa verbal yaitu tuturan siswa dalam membaca teks bahasa Arab. Selain itu alasan menggunakan desain analisis isi karena jenis penelitian ini mengungkap dan menggambarkan jenis kesalahan fonologis yang timbul ketika membaca teks bahasa Arab yang dilakukan oleh siswa.

Adapun metode penelitian bahasa yang digunakan peneliti adalah metode simak dengan teknik simak bebas libat cakap, teknik catat dan teknik rekam. Melalui

${ }^{5}$ H. Maghfur \& E. Fauziati. Strategi Belajar yang Tercermin dalam Kesalahan Interlanguage Siswa MAN I Surakarta. Jurnal Penelitian Humaniora, Vol. 16 No. 1, 2015, 21.

${ }^{6}$ C. Wahyuni. "Interferensi Bahasa dalam Maharah Kalam dan Kitabah Studi Analisis pada Mahasiswa PBA UIN Walisongo Semester V Tahun 2014”, Tesis, Yogyakarta. 2015, 4.

7 R. Safitri. "Analisis Kesalahan Fonologis dalam Bacaan Surah Al-Fatihah (Studi Deskriptif terhadap Kesalahan Fonologis pada Suku-suku Indonesia dalam Membaca Surah Al-Fatihah”, Tesis, Universitas Pendidikan Indonesia, 2015, 15. 
teknik simak bebas libat cakap, peneliti berperan sebagai pengamat penggunaan bahasa oleh para informan, dalam pengamatan tersebut tentunya membutuhkan teknik catat sebagai teknik untuk mengetahui realisasi fonem-fonem tertentu (misalnya dengan memanfaatkan fonetik artikulatoris) tidak hanya cukup dengan mendengarkan bunyibunyi yang dihasilkan oleh informan, tetapi juga harus melihat bagaimana bunyi itu dihasilkan. Kemudian teknik selanjutnya dalam metode simak bebas libat cakap adalah teknik rekam. Status teknik ini bersifat melengkapi kegiatan penyediaan data dengan teknik catat. Maksudnya apa yang dicatat itu dapat dicek kembali dengan rekaman yang dihasilkan. Selain itu teknik rekam ini digunakan karena data yang diamati berbentuk ujaran secara lisan. Adapun metode lain yang digunakan adalah metode analisis kesalahan yang bertujuan untuk mengukur kemajuan belajar bahasa dengan mencatat dan mengklasifikasikan kesalahan-kesalahan yang dibuat oleh siswa.

Partisipan dalam penelitian ini adalah lima siswa di kelas VII F SMP Plus Baiturrahman 2. Teknik pengambilan sampel ini menggunakan purposive sampling di mana peneliti menentukan sampel dengan pertimbangan dan kriteria tertentu sesuai dengan tujuan penelitian. Tujuan penelitian ini untuk mengungkapkan kesalahankesalahan fonologis siswa dalam keterampilan membaca teks bahasa Arab.

\section{Hasil Penelitian dan Pembahasan}

Kesalahan fonologis yaitu kesalahan pada tataran bunyi, baik pada level kata, frasa, klausa atau kalimat. Kesalahan ini hanya terjadi dalam penggunaan bahasa lisan, baik secara produktif (berbicara) maupun reseptif (mendengar). Dalam pembelajaran bahasa Arab bagi orang Indonesia, kesalahan fonologis banyak terjadi pada huruf yang sulit dilafalkan, seperti huruf ص ص ، شذ ،خ ، ث، ض، ط، ظ، ع، غ، ق. Banyaknya huruf ini tidak jarang membuat para pembelajar bingung dalam melafalkannya sehingga menimbulkan kesalahan fonologis. 8 Dalam penelitian ini para responden banyak melakukan kesalahan fonologis pada huruf ض dan $\mathcal{E}$, terbukti dengan tidak ada satu pun responden yang benar dalam melafalkan kedua huruf tersebut. Hal ini dikarenakan huruf ض dan $\varepsilon$ merupakan huruf yang ada dalam bahasa Arab tetapi tidak ada dalam bahasa Indonesia. ${ }^{9}$ Hal ini pun menjadi salah satu penyebab terjadinya kesalahan fonologis dalam keterampilan membaca.

Kesalahan fonologis yang ditemukan berupa ketidaksesuaian makhraj huruf dan ketidakmampuan siswa dalam membedakan huruf hijaiah yang berakibat dalam pengubahan satu huruf dengan huruf lainnya. Beberapa kesalahan yang terjadi pada siswa ketika proses pembelajaran keterampilan membaca, di antaranya ialah; tidak tepat dalam makharijul huruf, membaca kata demi kata, rendah dan tinggi bunyi huruf yang tidak sesuai dengan semestinya dan mengubah huruf dengan huruf yang lain. ${ }^{10}$ Kesalahan pada poin mengubah huruf dengan huruf lain dapat berpengaruh pada semantik. Ketepatan pengucapan dalam sebuah tuturan adalah hal yang penting karena

\footnotetext{
8 Setyawati. Analisis Kesalahan Berbahasa Indonesia, (Surakarta: Yuma Pustaka, 2013), 17.

9 A.S.A. Nasution. Fonetike \& Fonologi Alquran, (Jakarta: Amzah, 2012), 119.

${ }^{10}$ D. Rosyidin. "Metodik Khusus Pengajaran Bahasa Arab”, Tidak Diterbitkan. 2007, 13.
} 
dapat mempengaruhi makna yang dimaksud oleh penutur. ${ }^{11}$ Salah satu contohnya adalah kesalahan melafalkan huruf / $\varepsilon /$ menjadi / I/, atau sebaliknya huruf / I /menjadi

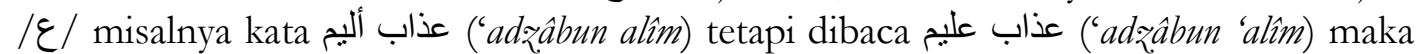
ini termasuk penyimpangan makna. Semula maknanya "siksa yang pedih" menjadi "siksa yang pintar". ${ }^{2}$ Adapun berikut dua kesalahan fonologis yang paling sulit dilafalkan oleh responden di antara beberapa kesalahan fonologis lain yaitu:

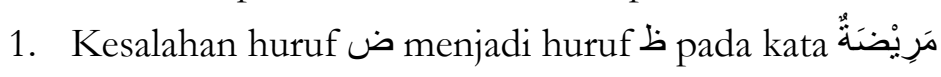

Huruf ض dideskripsikan sebagai konsonan yang keluar dari ujung lidah yang bertemu dengan gigi maka disebut dengan apiko-dental (طرف ضأسنانى). Adapun beberapa sifat huruf ض yaitu; Pertama, huruf ض termasuk kepada kategori jahar (جَ) artinya jelas, maksudnya ialah membunyikan huruf dengan tidak berdesis dan nafas tertahan, sehingga bunyi terdengar lebih jelas dan bersih. Kedua, huruf ض bersifat rakhawah (رخَاوَةُّ) artinya lunak, maksudnya membunyikan huruf dengan suara terlepas. Ketiga,

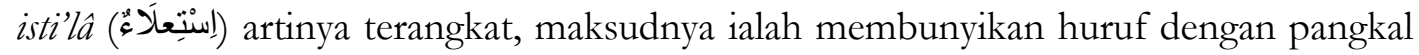
lidah ke langit-langit mulut, sehingga bunyi huruf menjadi lebih tinggi, tebal dan berat. Keempat, ithbâq (إِنْبَاٌُ) artinya tertutup, maksudnya membunyikan huruf dengan melengkungkan keliling lidah ke langit-langit mulut, sehingga bunyinya lebih besar dan

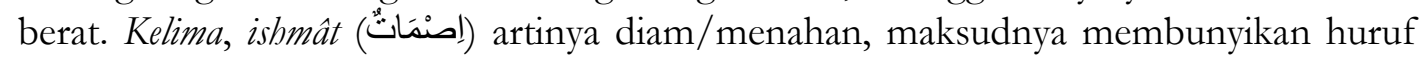
dengan berat dan tertahan. Itulah kelima sifat huruf ض ض yang akan membedakan

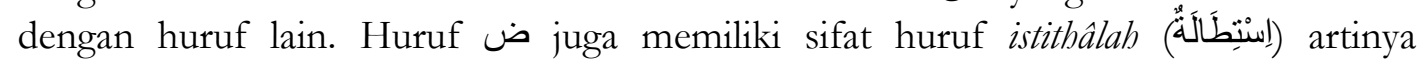
memanjang yang mana sifat ini membedakan huruf ض ض dengan huruf lainnya. Arti dari sifat tersebut membunyikan huruf dengan memanjang di salah satu tepi pangkal lidah sampai ke depan. Hurufnya ada satu yaitu $\omega^{13}$ Satu sifat tersebut membuktikan bahwa huruf ض menjadi huruf yang unik dalam bahasa Arab.

Berdasarkan pembagian jenis gelombang bunyi, huruf ض termasuk ke dalam konsonan yang memiliki bunyi letupan sehingga dalam pembagian gelombang bunyi berada pada kategori gelombang bunyi transien. Bunyi transien ditandai dengan durasinya yang sangat pendek sehingga keteraturannya sulit diidentifikasi. ${ }^{14}$ Untuk mengetahui kebenaran gelombang bunyi transien yang memiliki durasi pendek, maka berikut akan ditampilkan bentuk visualisasi tuturan huruf ض صَرِيْنَةُ y pada kang dilafalkan oleh penutur acuan sebagai acuan kebenaran bagi para responden.

${ }^{11}$ K. Wardana. "Kesalahan Artikulasi Phonemes Bahasa Inggris Mahasiswa Prodi Bahasa Inggris UNMAS Denpasar: Sebuah Kajian Fonologi Generatif”. Jurnal Bakti Saraswati, 2014, 77.

${ }^{12}$ D. Indrasari. "Analisis Kesalahan Fonologis pada Karangan Berbahasa Jawa Siswa Kelas III SD Negeri Kotagede 5 Yogyakarta Program Studi Pendidikan Guru Sekolah Dasar”. Tesis. Jurusan Pendidikan Prasekolah dan Sekolah Dasar Fakultas Ilmu Pendidikan Universitas Negeri Yogyakarta. 2015, 35.

${ }^{13}$ H. Al Rasyid. "Kontribusi Ulama Tajwid terhadap Perkembangan Ilmu Bahasa". Jurnal LAIN Medan Sumatra Utara, 2009, 207.

${ }^{14}$ Y. Irawan. Fonetik Akustik. (Bandung: Angkasa, 2017), 70. 
Ara6iyât Jurnal Pendidikan Bahasa Arab dan Kebahasaaraban, 4 (2), 2017

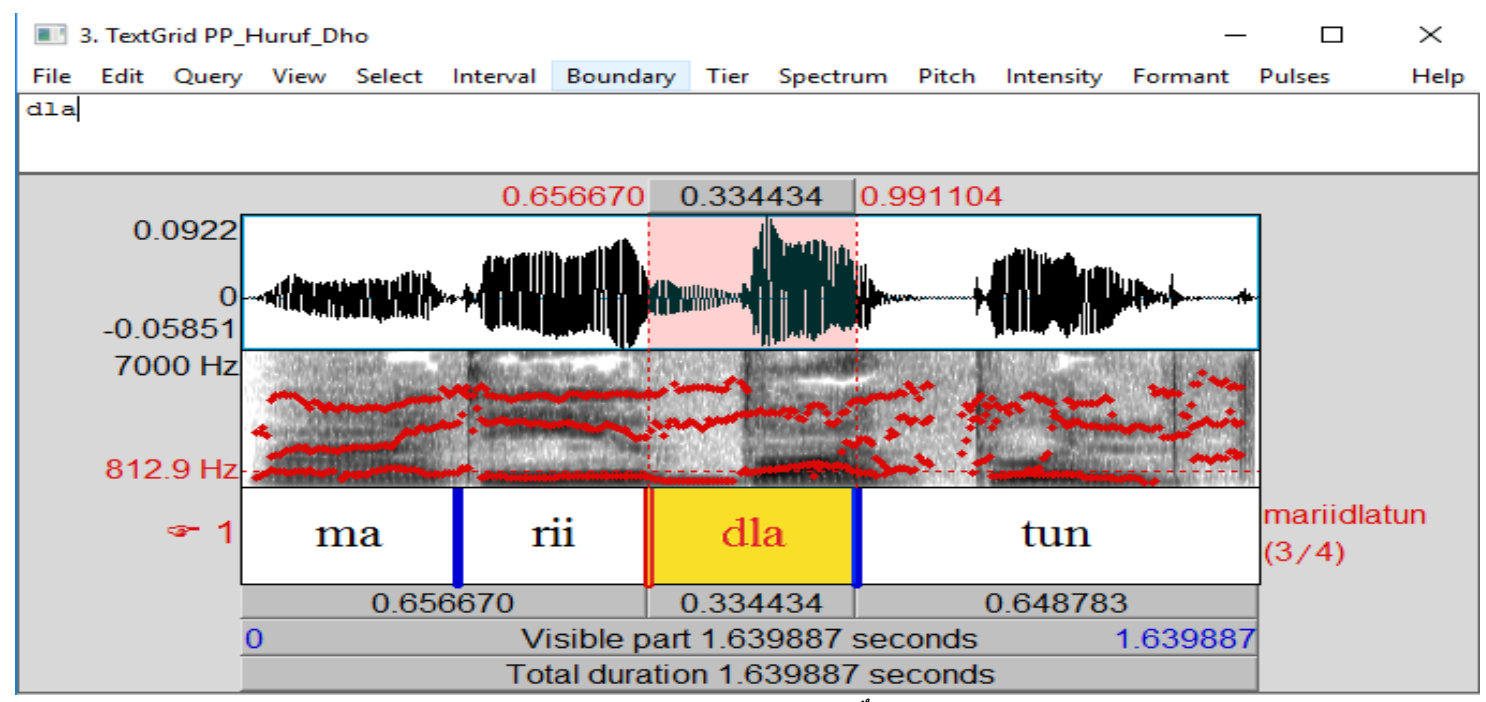

\section{Gambar 1 visualisasi anotasi pada kata “مَرِيْضَةُّ" oleh penutur acuan}

Anotasi tuturan di atas peneliti sajikan agar para pembaca mengetahui tuturan keseluruhan yang akan dianalisis untuk huruf ض. Sedangkan berikut adalah tuturan huruf ض setelah dilakukan segmentasi.

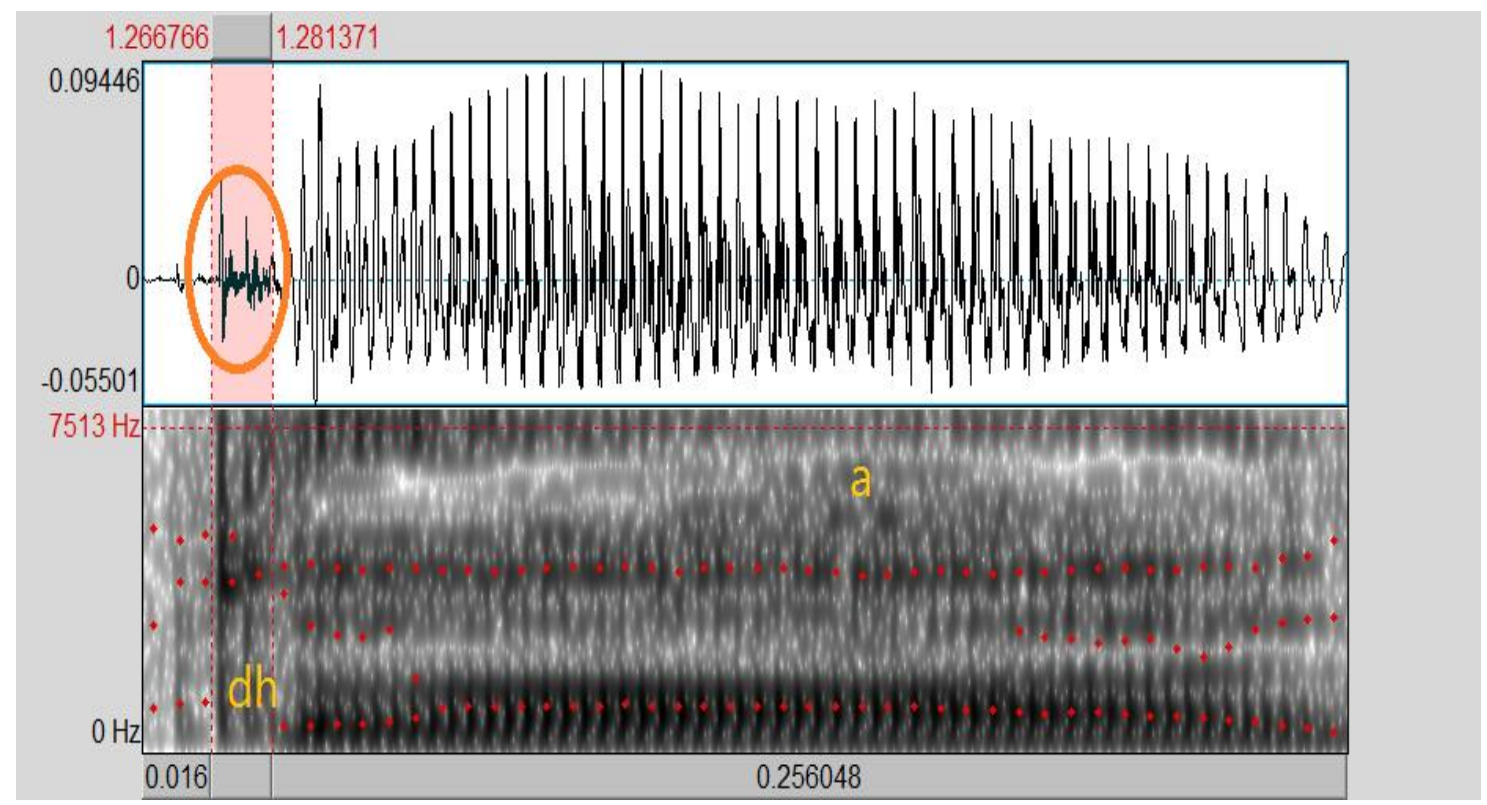

ض ض Gambar visualisasi gelombang suara dan spektrogram dari pelafalan huruf pada kata “مَرِيْضَة" oleh penutur acuan

Lingkaran yang terdapat dalam gambar di atas menunjukkan bahwa gelombang bunyi huruf ض sangatlah pendek. Hal ini karena huruf ض termasuk ke dalam gelombang bunyi transien atau bunyi letupan. Tuturan penutur acuan ini menjadi acuan bagi repsoden dalam melafalkan huruf ض ض. Tetapi, hasil dari analisis data menunjukkan bahwa semua responden tidak memiliki tuturan yang benar atau 
mendekati kebenaran tuturan penutur acuan. Pada umumnya kesalahan huruf ض terletak pada makhraj yang sulit dan berat untuk diucapkan. Seperti yang ditimbulkan oleh responden 01, 02, 03 dan 05. Makhraj yang sulit dan berat diucapkan inilah yang

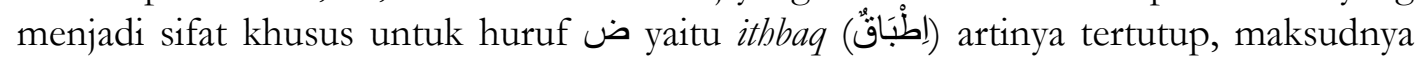
membunyikan huruf dengan melengkungkan keliling lidah ke langit-langit mulut, sehingga bunyinya lebih besar dan berat. ${ }^{15}$ Adapun satu responden yang memiliki kesalahan paling fatal adalah dengan mengubah huruf ض menjadi huruf lain yang dilakukan oleh responden 04 , berikut adalah bentuk visualisasi tuturannya:

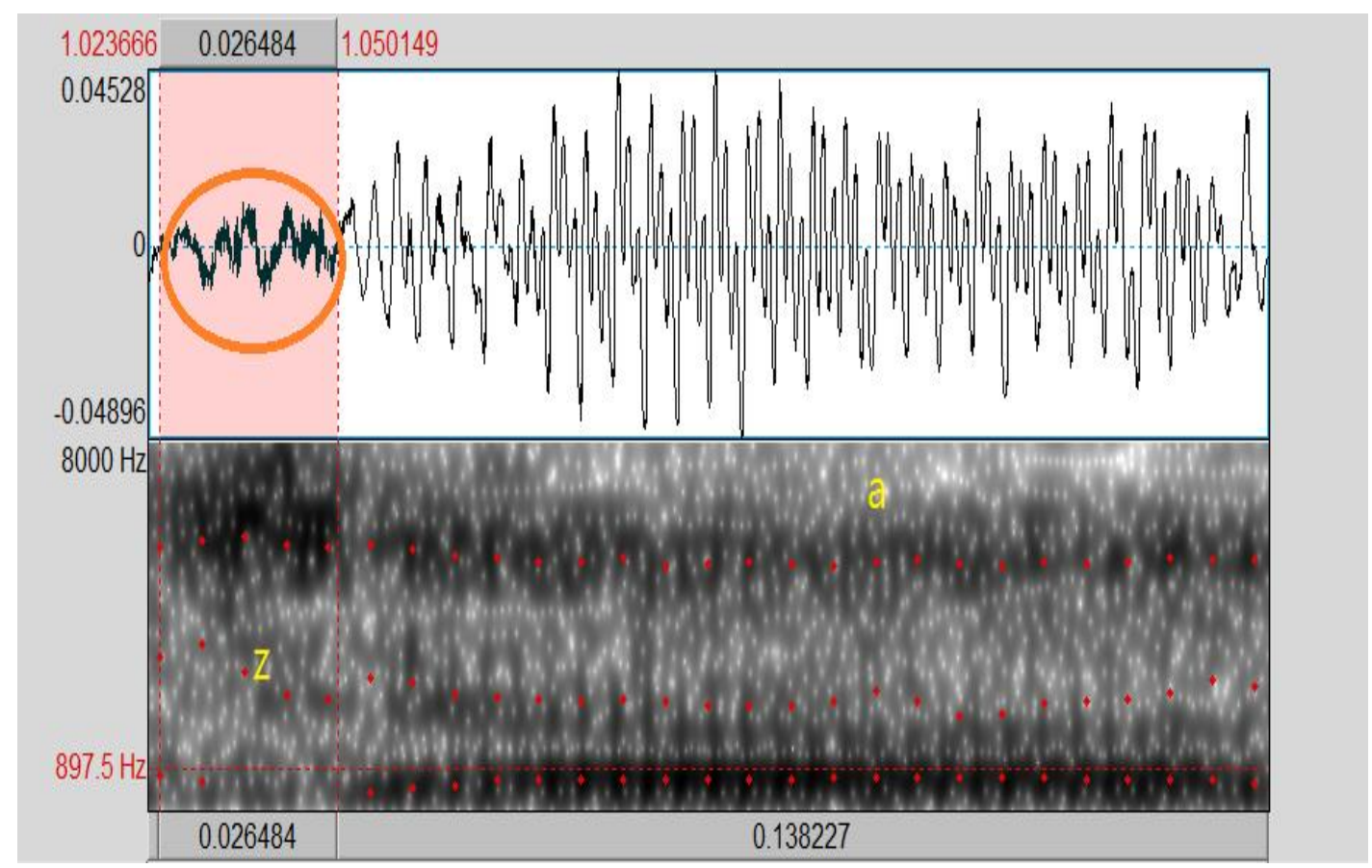

\section{Gambar visualisasi gelombang suara dan spektrogram dari pelafalan huruf ض pada kata “مَرِيضَنَ" oleh responden 04}

Seperti yang disajikan pada gambar di atas ini, bahwa responden 04 memiliki letak kesalahan dengan mengubah huruf ض menjadi huruf ל, padahal kedua huruf tersebut memiliki perbedaan titik artikulasi. Yang mana huruf bideskripsikan sebagai konsonan apiko-interdental sedangkan huruf ض sebagai konsonan apikodental. ${ }^{16}$ Begitupun berdasarkan jenis gelombang bunyi yang mana keduanya memiliki perbedaan, huruf termasuk bunyi frikatif yang disebut dengan gelombang bunyi aperiodik, sedangkan huruf ض termasuk bunyi letupan yang disebut dengan gelombang bunyi transien. Kesalahan pelafalan ini akan berdampak pada arti kata atau

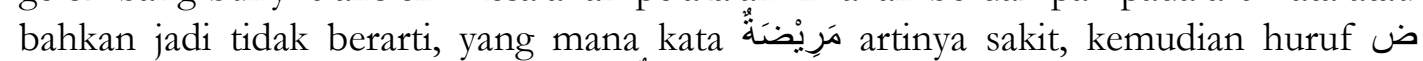

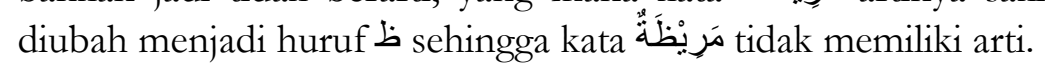

15 Al Rasyid. "Kontribusi Ulama Tajwid terhadap Perkembangan Ilmu Bahasa”, 207.

16 A.S.A. Nasution. Fonetik \& Fonologi Alquran, 119. 


\section{Kesalahan huruf}

Titik artikulasi dari huruf $\varepsilon$ adalah wastbul halq (وسط الحلق), namun biasa dikenal dengan faringal. Huruf $\varepsilon$ memiliki empat sifat huruf yaitu; Pertama, huruf $\varepsilon$ termasuk kepada kategori jahar (جَ) artinya jelas, maksudnya ialah membunyikan huruf dengan tidak berdesis dan nafas tertahan, sehingga bunyi terdengar lebih jelas dan bersih. Kedua, huruf $\varepsilon$ bersifat istifal (إستْنَفَّلَ) artinya turun, maksudnya membunyikan huruf dengan menurunkan pangkal lidah ke langit-langit mulut, sehingga bunyi huruf

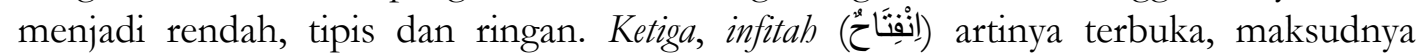
membunyikan huruf dengan pertengahan lidah terbuka. Keempat, ishmat (إصنَّاتُ diam atau menahan, maksudnya ialah membunyikan huruf dengan berat dan tertahan. ${ }^{17}$ Sedangkan dalam pembagian jenis gelombang bunyi, huruf $\varepsilon$ termasuk ke dalam bunyi frikatif atau gelombang bunyi aperiodik. Gelombang bunyi aperiodik tidak ditandai oleh pengulangan teratur sehingga gelombang ini tidak memiliki frekuensi atau frekuensinya sulit untuk ditentukan. ${ }^{18}$ Di bawah ini adalah bentuk dari gelombang bunyi aperiodik untuk huruf $\varepsilon$.

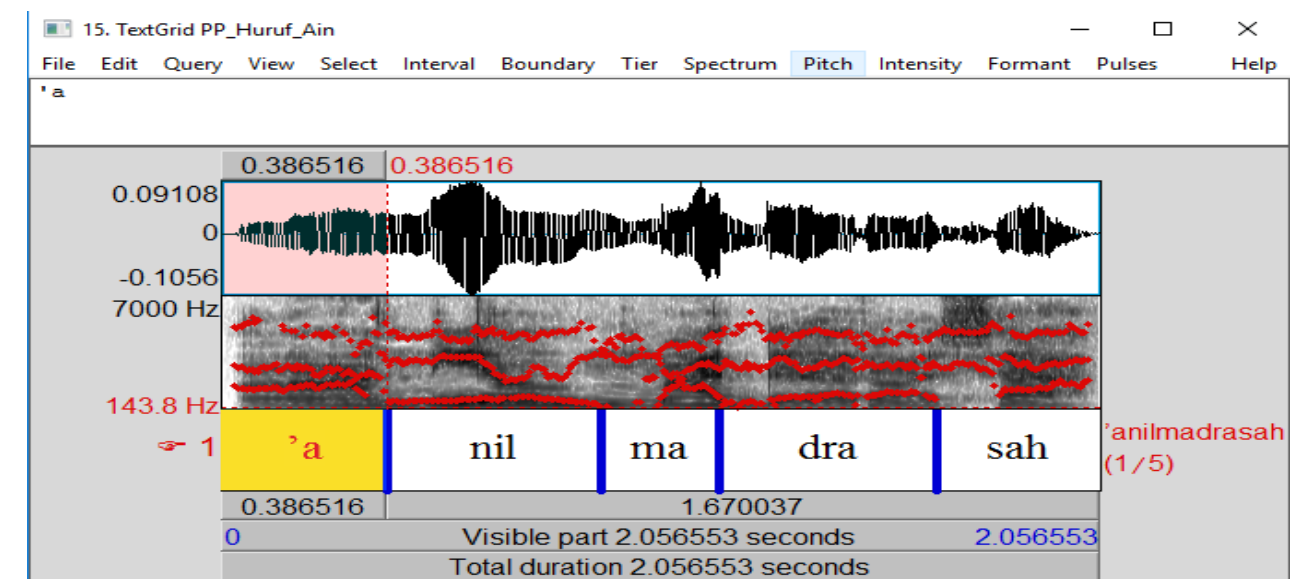

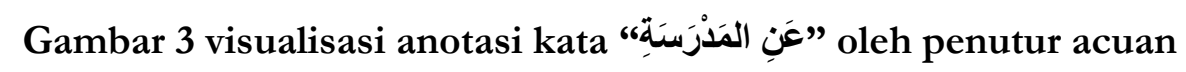

Anotasi tuturan di atas peneliti sajikan agar para pembaca mengetahui tuturan keseluruhan yang akan dianalisis untuk huruf $\varepsilon$. Sedangkan berikut adalah tuturan huruf $\varepsilon$ setelah dilakukan segmentasi.

${ }^{17}$ H. Al Rasyid. "Kontribusi Ulama Tajwid terhadap Perkembangan Ilmu Bahasa”, 207.

18 Y. Irawan. Fonetik Akustik. Angkasa, 70. 


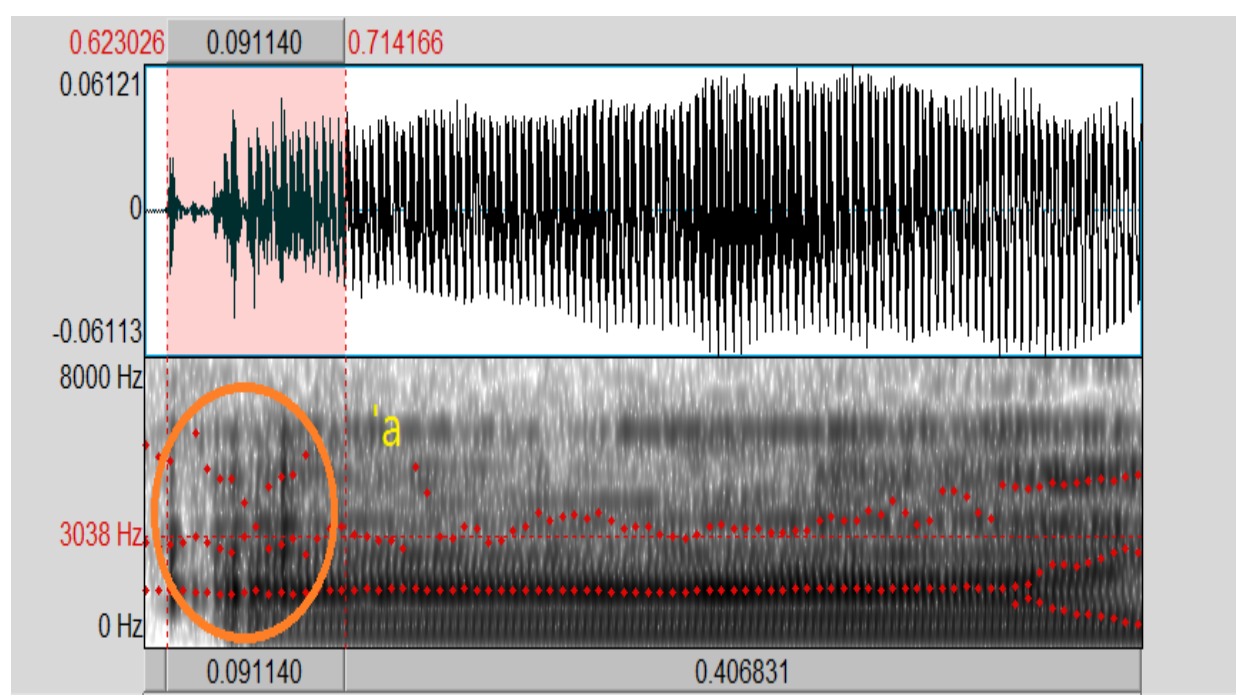

\section{Gambar 4 visualisasi gelombang suara dan spektrogram dari pelafalan huruf $\varepsilon$ pada kata عَنِ المَدَرَسَتِِة oleh penutur acuan}

Sebagaimana yang telah dipaparkan sebelumnya bahwa huruf $\varepsilon$ termasuk bunyi frikatif, hal ini ditunjukkan dengan bentuk gelombang bunyi yang tidak teratur. Bentuk gelombang seperti itu termasuk ke dalam gelombang bunyi aperiodik tidak ditandai dengan pengulangan teratur sehingga gelombang bunyi ini tdak memiliki frekuensinya sulit ditentukan. Selain itu hal lain ditunjukkan oleh area yang diberi lingkaran pada gambar di atas. Area tersebut memiliki titik-titik merah yang kita sebut dengan forman. Forman yang tidak beraturan tersebut menunjukkan bahwa adanya huruf konsonan yang dilafalkan oleh penutur. Pada bagian atas lingkaran tersebut memiliki area spektrum yang cenderung lebih tipis dibanding area yang lain. Padahal semakin hitam area spektrum dalam sebuah tuturan menunjukkan semakin besar energi bunyi yang dihasilkan penutur. ${ }^{19}$ Tipisnya area di atas karena huruf $\varepsilon$ memiliki sifat istifâl sehingga bunyi yang dihasilkan berbentuk tipis dan rendah, dan salah satu sifat huruf $\varepsilon$ adalah istifâl.

Tuturan di atas merupakan acuan untuk menilai kesalahan yang ditimbulkan oleh para responden. Ternyata kesalahan fonologis yang dilakukan oleh responden 01, 02, 04 dan 05 pada huruf $\varepsilon$ mayoritas terjadi karena kurang tepatnya makhraj huruf tersebut. Sehingga kesalahan fatal akibat kurang tepatnya makhraj adalah berubahnya huruf $\varepsilon$ menjadi huruf I. Seperti yang terjadi pada tuturan responden 03 di bawah ini:

${ }^{19}$ Y. Irawan. Fonetik Akustik, 70.

${ }^{20}$ H. Al Rasyid. "Kontribusi Ulama Tajwid terhadap Perkembangan Ilmu Bahasa”, 207. 


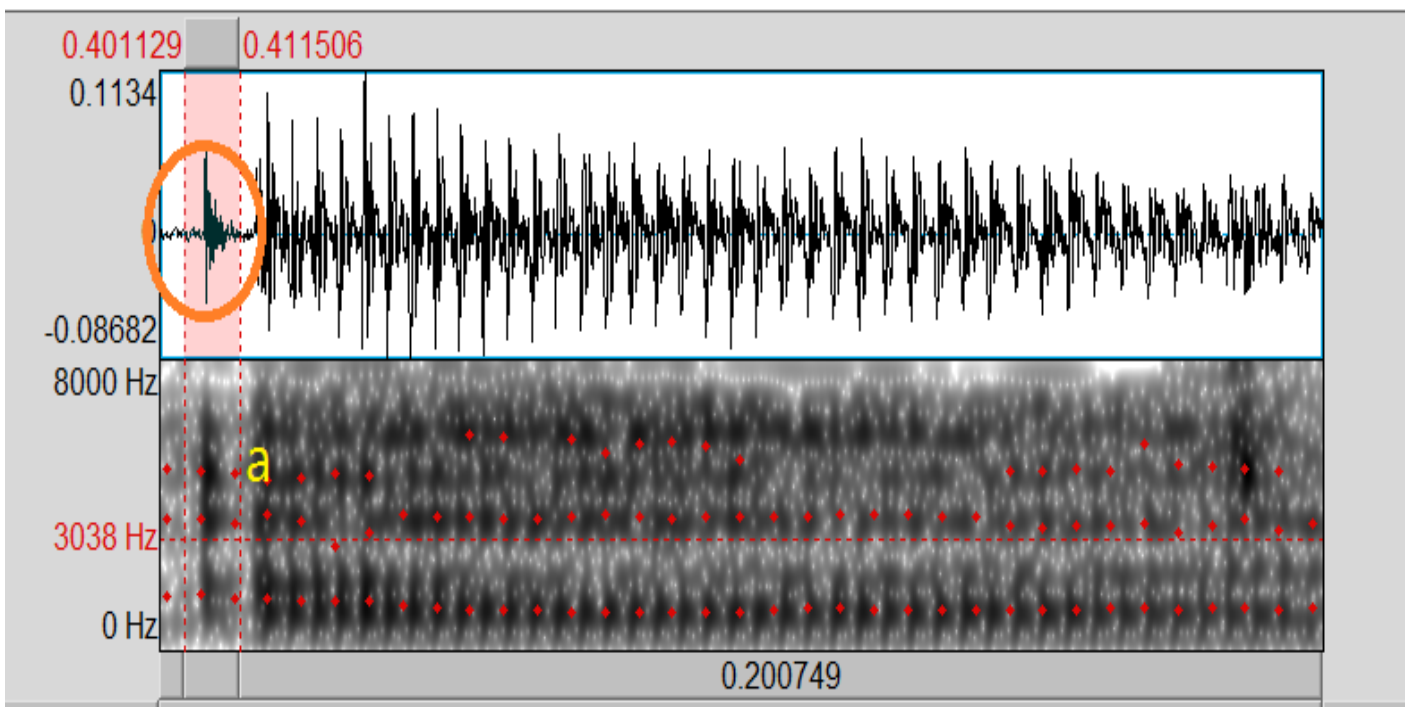

Gambar 4 visualisasi gelombang suara dan spektrogram dari pelafalan huruf $\varepsilon$ pada kata عَنِ المَدَرَسَنَة oleh responden 03

Gelombang bunyi yang diberi lingkaran menunjukkan adanya bunyi transien atau bunyi letupan. Bunyi letupan inilah yang menunjukkan bahwa responden 03 mengubah huruf $\varepsilon$ menjadi huruf $\{$. Karena seperti yang telah dipaparkan di atas bahwa huruf $\varepsilon$ jika dilafalkan akan membentuk bunyi frikatif bukan bunyi letupan. ${ }^{21}$ Huruf i dideskripsikan dengan glottal/letupan/bersuara/ sedangkan huruf $\varepsilon$ dideskripsikan dengan faringal/geseran (frikatif)/bersuara. Selain itu berdasarkan sifat huruf, bahwa huruf I memiliki sifat syiddah (نَدَّنَ) artinya kuat. Maksudnya ialah membunyikan huruf dengan suara tertahan dan lebih kuat tertahannya ketika mati atau waqaf. Sedangkan huruf $\varepsilon$ tidak memiliki sifat tersebut. ${ }^{22}$ Dengan begitu, jelaslah jika tuturan responden 03 menimbulkan kesalahan fonologis, yaitu dengan mengubah suatu huruf dengan huruf lainnya. Hal ini bisa berpengaruh pada semantik, yaitu hilangnya arti atau memiliki arti lain..

\section{Simpulan}

Berdasarkan hasil analisis tersebut dapat disimpulkan bahwa dalam proses pembelajaran keterampilan membaca, para siswa menimbulkan kesalahan ucap atau biasa disebut dengan kesalahan fonologis. Kesalahan fonologis ini terjadi pada huruf bijaiyyah berupa konsonan yang tidak memiliki padanan dalam bahasa pertama yaitu huruf $\varepsilon$ dan huruf ض. Masing-masing huruf merupakan konsonan yang menghasilkan bunyi frikatif dan letupan. Adapun huruf ض merupakan huruf yang paling berat untuk dilafalkan oleh penutur non-Arab karena memiliki sifat huruf yang khusus, yang mana

${ }^{21}$ Y. Irawan. Fonetik, Akustik, 70.

${ }^{22}$ Al Rasyid. "Kontribusi Ulama Tajwid terhadap Perkembangan Ilmu Bahasa”, 207. 
tidak dimiliki oleh huruf lain. Hal ini membuktikan bahwa huruf ض menjadi huruf yang unik dalam bahasa Arab.[]

\section{DAFTAR RUJUKAN}

Indrasari, D. "Analisis Kesalahan Fonologis pada Karangan Berbahasa Jawa Siswa Kelas III SD Negeri Kotagede 5 Yogyakarta”. Tesis. Program Studi Pendidikan Guru Sekolah Dasar Jurusan Pendidikan Prasekolah dan Sekolah Dasar Fakultas Ilmu Pendidikan Universitas Negeri Yogyakarta, 2015.

Irawan, Y. Fonetik Akustik. Bandung: Angkasa, 2017.

Lubis, S.E. “Orientalis dan Bahasa Arab”. Jurnal Forum Pedagogik. Vol. 7 No. 2, 2015.

Maghfur, H. \& Fauziati, E. "Strategi Belajar yang Tercermin dalam Kesalahan Interlanguage Siswa MAN I Surakarta”. Jurnal Penelitian Humaniora, Vol. 16 No. $1,2015$.

Nasution, A.S.A. Fonetik \& Fonologi Alquran. Jakarta: Amzah, 2012.

Al Rasyid, H. "Kontribusi Ulama Tajwid terhadap Perkembangan Ilmu Bahasa”. Jurnal IAIN Medan Sumatra Utara. Vol. 2 No. 2, 2009.

Rosyidin, D. "Metodik Khusus Pengajaran Bahasa Arab”. Tidak Diterbitkan, 2007.

Safitri, R. Analisis Kesalahan Fonologis dalam Bacaan Surah Al-Fatihah (Studi Deskriptif terhadap Kesalahan Fonologis pada Suku-suku Indonesia dalam Membaca Surah AlFatihah. Bandung: Universitas Pendidikan Indonesia, 2015.

Setyawati. Analisis Kesalahan Berbahasa Indonesia. Surakarta: Yuma Pustaka, 2013.

Subali, M. Andriansyah, M. \& Sinambela, C. "Frekuensi Forman sebagai Model Akustik Tabung Sederhana dari Vocal Tract". Prosiding Seminar Nasional Aplikasi Sains \& Teknologi (SNAST). Yogyakarta, 2014.

Wahyuni, C. "Interferensi Bahasa dalam Maharah Kalam dan Kitabah Studi Analisis pada Mahasiswa PBA UIN Walisongo Semester V Tahun 2014", Tesis, Yogyakarta: UIN Sunan Kalijaga, 2015.

Wardana, K. "Kesalahan Artikulasi Phonemes Bahasa Inggris Mahasiswa Prodi Bahasa Inggris UNMAS Denpasar: Sebuah Kajian Fonologi Generatif'. Jurnal Bakti Saraswati. Vol. 3 No. 2, 2014. 